\title{
Polychaete species diversity in the central Pacific abyss: local and regional patterns, and relationships with productivity
}

\author{
A. G. Glover ${ }^{1,2, *}$, C. R. Smith ${ }^{1}$, G. L. J. Paterson ${ }^{2}$, G. D. F. Wilson ${ }^{3}$, L. Hawkins ${ }^{4}$, \\ M. Sheader ${ }^{4}$ \\ ${ }^{1}$ Department of Oceanography, University of Hawaii, 1000 Pope Rd, Honolulu, Hawaii 96822, USA \\ ${ }^{2}$ Zoology Department, The Natural History Museum, Cromwell Rd, London SW7 5BD, United Kingdom \\ ${ }^{3}$ Division of Invertebrate Zoology, Australian Museum, 6 College St, Sydney, New South Wales 2010, Australia \\ ${ }^{4}$ School of Ocean and Earth Science, University of Southampton, Southampton Oceanography Center, European Way, \\ Southampton SO14 3ZH, United Kingdom
}

\begin{abstract}
We investigated the relationship between productivity and local species diversity, and the degree of species turnover, at 8 sites on the central equatorial Pacific abyssal plain. The 8 sites span a 4 -fold difference in seafloor particulate organic carbon (POC) flux and, hence, community productivity. The sites are similar in water depth (4300 to $5100 \mathrm{~m}$ ), degree of isolation from terrigenous influences, and hydrodynamic regime. Three sites lie under the influence of equatorial upwelling, and are subject to enhanced deep POC flux derived from high overlying primary production. The remaining sites lie beneath the oligotrophic north Pacific gyre. The number of polychaete species collected at a single site ranged from 14 to 113, with at least $90 \%$ apparently being new to science. We found no evidence for the purported unimodal relationship between productivity and diversity seen in other ecosystems, including deep-sea slopes, and found only weak evidence of a monotonic increase in diversity with productivity. Rates of species turnover were low over scales of $\sim 200$ to $3000 \mathrm{~km}$ for the dominant polychaete species in the communities, and all sites were dominated by a core group of biogeographically widespread, locally abundant species. In contrast, there was little between-site similarity in the long list of rare species found at each site, implying either a high turnover of rare species at 200 to $3000 \mathrm{~km}$ scales, or incomplete sampling of the rare species list at each site. More intensive sampling studies using both morphological and molecular methods are needed to resolve the distribution patterns of rare species in the Pacific abyss. Local polychaete species diversity beneath equatorial Pacific upwelling (measured by rarefaction) appears to be unusually high for the deep sea, exceeding by at least 10 to $20 \%$ that measured in abyssal sites in the Atlantic and Pacific, and on the continental slopes of the North Atlantic, North Pacific, and Indian Oceans.
\end{abstract}

KEY WORDS: Polychaetes $\cdot$ Pacific $\cdot$ Species diversity $\cdot$ Carbon flux $\cdot$ Productivity $\cdot$ Species turnover $\cdot$ Alpha diversity $\cdot$ Beta diversity

\section{INTRODUCTION}

Studies in a variety of habitats, both terrestrial and marine, demonstrate a unimodal relationship between productivity and species diversity (e.g. Rosenzweig \&

*E-mail: adrian@adrianglover.com
Abramsky 1993, Waide et al. 1999). The unimodal curve may occur on regional scales for a broad range of terrestrial taxa, and it is postulated to apply on local to regional scales for deep-sea macrobenthos along bathymetric (and presumed productivity) gradients (e.g. Rex 1981, Rosenzweig \& Abramsky 1993, Rosenzweig 1995). While particulate organic carbon (POC)

() Inter-Research $2002 \cdot$ www.int-res.com 
flux (and hence food availability and community productivity) decreases with increasing water depth in the ocean (e.g. Suess 1980, Martin et al. 1987), many parameters besides productivity often covary with depth, including terrigenous input, current energy, and hydrostatic pressure (e.g. Carney et al. 1983, Gage \& Tyler 1991). Thus, diversity changes along an oceanic depth gradient are difficult to ascribe solely to variations in community productivity.

The influence of productivity on the diversity of deepsea benthos is of particular interest because (1) deepsea habitats appear to have extraordinary levels of local, and possibly, global diversity (Hessler \& Jumars 1974, Grassle \& Maciolek 1992, Snelgrove \& Smith in press), and (2) the factors controlling these high diversity levels are poorly understood. Any unified theory of species diversity must explain patterns in deep-sea sediments, one of Earth's largest and potentially most species-rich biotopes (Grassle \& Maciolek 1992, Snelgrove \& Smith in press).

The abyssal North Pacific provides a useful setting to explore productivity-diversity relationships for at least 2 reasons. POC flux to the seafloor (which controls productivity in most deep-sea habitats) varies dramatically due to equatorial upwelling, while other variables (in particular, depth, continental influences, and hydrodynamic regime) remain relatively constant. In addition, the Pacific abyssal seafloor is the most extensive of deepsea sedimentary habitats. In this study, we use data from the Joint Global Ocean Flux (JGOFS) Equatorial Pacific Study, and baseline data from nodule-mining impact studies, to investigate (1) the relationship between productivity and local species diversity, and (2) species turnover between sites separated by 200 to $3000 \mathrm{~km}$ in the abyssal Pacific.

The causes behind unimodal productivity-diversity relationships are controversial (Rosenzweig \& Abramsky 1993, Waide et al. 1999, Levin et al. 2001). Diversity is thought to initially increase with increasing productivity because of a rise in the number of species that can maintain a minimum viable population size. At high levels of productivity, diversity may decrease, possibly due to reduced spatial heterogeneity of food resources, changes in competitive structure, or enhanced environmental stress (Rosenzweig \& Abramsky 1993, Levin et al. 2001). Our abyssal study sites range from the extremely food-poor central Pacific gyre (Hessler \& Jumars 1974) to the relatively productive equatorial zone (Berelson et al. 1994, Smith et al. 1997); if productivity fundamentally influences species diversity in the deep sea, we predict a strong diversityproductivity relationship across our study sites.

Spatial patterns of species turnover in the abyssal deep sea are very poorly studied. Paterson et al. (1998) found evidence of measurable macrobenthic species turnover over distances of 400 to $3000 \mathrm{~km}$ in the abyssal Atlantic and Pacific, although Glover et al. (2001) suggested that spatial differences among the Atlantic sites may be explained by undersampling of the sparse, species-rich abyssal fauna. If species turnover is significant over scales of $>1000 \mathrm{~km}$ in the abyss as postulated by Paterson et al. (1998), we predict that turnover will be evident even among macrofaunal community dominants on spatial scales of $3000 \mathrm{~km}$ in the Pacific abyss.

To test these predictions, we focus on the polychaete component of the macrobenthos because this taxon constitutes the bulk of macrofaunal abundance and species richness at abyssal depths (Paterson et al. 1998, Glover et al. 2001) and because the polychaetes are relatively tractable to detailed taxonomic analyses.

\section{DESCRIPTION OF STUDY SITES}

The EqPac study formed part of US Joint Global Ocean Flux Study, the major goals of which are to determine the processes controlling the flux of carbon and other biogenic elements in the oceans and to quantify exchanges with the atmosphere, sea floor and continental margins (Murray et al. 1997). The EqPac samples were collected in November 1992 aboard the $\mathrm{RV}$ 'Thomas Thompson' at $0^{\circ}, 2^{\circ}, 5^{\circ}$ and $9^{\circ} \mathrm{N}, 140^{\circ} \mathrm{W}$ in 4300 to $4900 \mathrm{~m}$ of water (Fig. 1, Table 1) (Smith 1992). As part of C. Smith's EqPac project, a series of box cores were also collected from the Hawaii Ocean Time Series (HOT) station at $23^{\circ} \mathrm{N}, 158^{\circ} \mathrm{W}$ (Karl \& Lukas 1996). The collections were made in August 1992 and February 1993 aboard the RV 'Moana Wave'.

The manganese nodule-mining province between the Clarion and Clipperton Fracture Zones (CCFZ) was intensively studied as part of the Deep Ocean Mining Environmental Study (DOMES) (Piper \& Blueford 1982), the ECHO 1 expedition (Wilson \& Hessler 1987) and the Preservational Reserve Area (PRA) study (Wilson 1990, Wilson 1992). We analyzed data from DOMES site A $\left(8^{\circ} 27^{\prime} \mathrm{N}, 150^{\circ} 47^{\prime} \mathrm{W}\right)$, ECHO $1\left(14^{\circ} 40^{\prime} \mathrm{N}\right.$, $\left.126^{\circ} 25^{\prime} \mathrm{W}\right)$ and PRA sites $\left(12^{\circ} 57^{\prime} \mathrm{N}, 128^{\circ} 19^{\prime} \mathrm{W}\right)$. The DOMES Site A samples were collected aboard the RV 'Oceanographer' in 1977/78 as part of a study of the effects of trial mining for manganese nodules. The ECHO 1 samples were collected in 1982 at another test mining area by the RV 'Melville' (Spiess et al. 1987). No differences in community structure or diversity were found between test sites and undisturbed control sites, although this may be a consequence of undersampling of the communities (Wilson \& Hessler 1987). The PRA samples were collected in 1989 by the RV 'Moana Wave' in a baseline study of a site designated as a reserve from any future manganese nodule mining (Wilson 1990, 1992). 


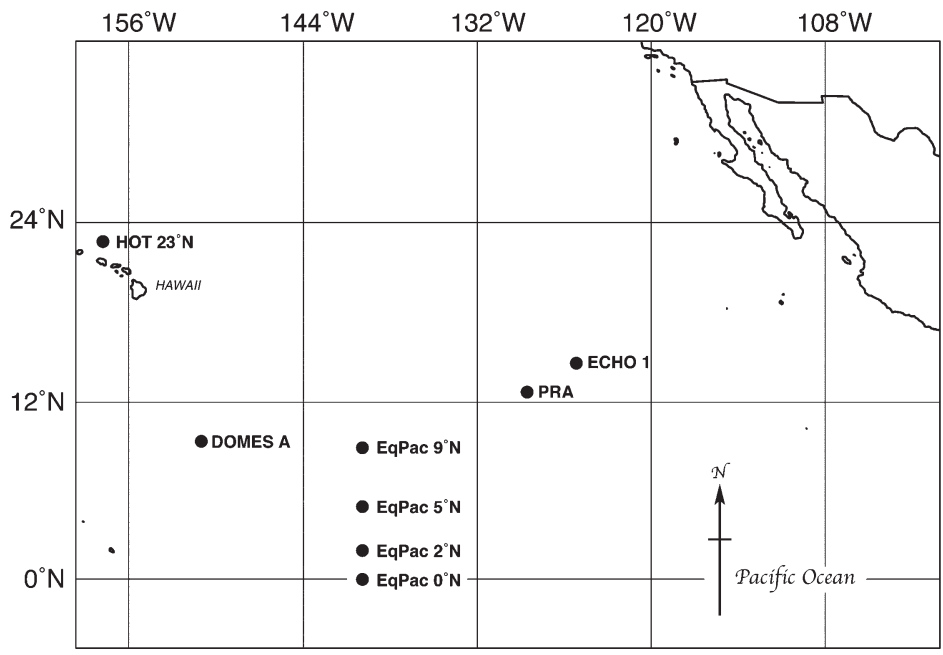

Fig. 1. The central equatorial Pacific, indicating the locations of sampling sites along the Equatorial Pacific JGOFS transect and within the Clarion-Clipperton Fracture Zone

Upwelling of nutrient rich water in the central and eastern equatorial Pacific Ocean fuels new biological production that could account for as much as 25 to $50 \%$ of the total global value (Chavez \& Barber 1987). Images from the SeaWiFS ocean color sensing satellite demonstrate that the band of equatorial productivity extends from the coast of Ecuador to at least $150^{\circ} \mathrm{W}$. The EqPac sites at $0^{\circ} \mathrm{N}, 2^{\circ} \mathrm{N}$ and $5^{\circ} \mathrm{N}$ lie within the influence of equatorial upwelling, while the remaining sites lie in the central north Pacific oligotrophic gyre region (Smith et al. 1997, Smith \& Demopoulos in press). Estimates of averaged annual primary productivity, taken from the Rutgers University Ocean Primary Productivity group website (http://marine.rutgers.edu/opp/), and based on SeaWIFS data, are provided in Table 1 (Behrenfeld \& Falkowski 1997). Data on deep POC flux, as reported in
Smith et al. (1997), are also provided in Table 1. No POC flux measurements were available for the CCFZ sites, although their surface productivity regimes and sediment characteristics are similar to those at the EqPac $9^{\circ} \mathrm{N}$ site, which also lies within the CCFZ manganese nodule zone.

The presence of substantial amounts of fresh phytoplankton detritus (or phytodetritus) has been recorded at the EqPac $0^{\circ} \mathrm{N}, 2^{\circ} \mathrm{N}$ and $5^{\circ} \mathrm{N}$ sites, but not at any of the other EqPac sites, or in the CCFZ region (Smith et al. 1996). The authors concluded that this phytodetritus was an important food source for benthic microbes and metazoans. Rates of bioturbation are higher at 0 to $5^{\circ} \mathrm{N}$ than at $9^{\circ} \mathrm{N}$ and macrofaunal abundance along the EqPac transect is strongly correlated with deep POC flux (Smith et al. 1997).

\section{MATERIALS AND METHODS}

Sample collection and processing. All the samples were collected using a USNEL spade box core (Hessler \& Jumars 1974). Samples were washed on a $300 \mu \mathrm{m}$ sieve, fixed in $10 \%$ formalin for $>24 \mathrm{~h}$ and transferred to 70 to $80 \%$ ethanol for permanent storage. Standard box core washing methods developed by R. Hessler (Hessler \& Jumars 1974) were used on all cruises. In the laboratory, all the macrofaunal specimens were taken out and polychaetes were first sorted to family, and then to the species level. The specimens from DOMES A were identified by K. Fauchald, those from ECHO 1 and PRA by K. Fitzhugh and those from EqPac and HOT stations by A. Glover. Species identifications for the DOMES A specimens were cross-checked with the remaining CCFZ specimens by K. Fitzhugh. The EqPac and HOT specimens have not been cross-

Table 1. Site, position depth, number of USNEL spade box core samples, averaged annual surface productivity (Behrenfeld \& Falkowski 1997), deep POC flux estimates (Smith et al. 1997), mean abundance of polychaetes per $0.25 \mathrm{~m}^{2}$ and total number of species. Note that only polychaetes identified to species level are included in the abundance calculation. All sites significantly different in terms of abundance per $0.25 \mathrm{~m}^{2}$ (ANOVA $\mathrm{p}<0.05$ ), except $0^{\circ} \mathrm{N}$ and $5^{\circ} \mathrm{N}, 2^{\circ} \mathrm{N}$ and $5^{\circ} \mathrm{N}, 2^{\circ} \mathrm{N}$ and $\mathrm{PRA}, 9^{\circ} \mathrm{N}$ and DOMES A, $23^{\circ} \mathrm{N}$ and $9^{\circ} \mathrm{N}, 23^{\circ} \mathrm{N}$ and DOMES A

\begin{tabular}{|c|c|c|c|c|c|c|c|}
\hline Site & Position & $\begin{array}{l}\text { Depth } \\
\text { (m) }\end{array}$ & $\begin{array}{c}\text { No. of } \\
\text { box cores }\end{array}$ & $\begin{array}{l}\text { Average annual } \\
\text { surface productivity } \\
\quad\left(\mathrm{g} \mathrm{C} \mathrm{m}^{-2} \mathrm{yr}^{-1}\right)\end{array}$ & $\begin{array}{c}\text { POC flux } \\
\text { at } 2000 \mathrm{~m} \\
\left(\mathrm{gC} \mathrm{m}^{-2} \mathrm{yr}^{-1}\right)\end{array}$ & $\begin{array}{c}\text { Abundance } \\
0.25 \mathrm{~m}^{-2} \\
(\mathrm{SE})\end{array}$ & $\begin{array}{c}\text { No. of } \\
\text { species }\end{array}$ \\
\hline EQPAC $0^{\circ} \mathrm{N}$ & $0^{\circ} \mathrm{N}, 140^{\circ} \mathrm{W}$ & 4300 & 3 & 230 & 1.6 & $84(27.9)$ & 73 \\
\hline $\mathrm{EQPAC} 2{ }^{\circ} \mathrm{N}$ & $2^{\circ} \mathrm{N}, 140^{\circ} \mathrm{W}$ & 4400 & 4 & 200 & 1.3 & $60(6.4)$ & 82 \\
\hline $\mathrm{EQPAC} 5^{\circ} \mathrm{N}$ & $5^{\circ} \mathrm{N}, 140^{\circ} \mathrm{W}$ & 4400 & 3 & 155 & 1.4 & $80(19.1)$ & 76 \\
\hline EQPAC $9^{\circ} \mathrm{N}$ & $9^{\circ} \mathrm{N}, 140^{\circ} \mathrm{W}$ & 4900 & 3 & 140 & 0.44 & $13(2.3)$ & 23 \\
\hline $\mathrm{HOT} 23^{\circ} \mathrm{N}$ & $23^{\circ} \mathrm{N}, 158^{\circ} \mathrm{W}$ & 4800 & 4 & 105 & 0.4 & $9(1.7)$ & 14 \\
\hline DOMES A & $8^{\circ} 27^{\prime} \mathrm{N}, 150^{\circ} 47^{\prime} \mathrm{W}$ & 5100 & 47 & 140 & N/A & $16(0.8)$ & 104 \\
\hline PRA & $12^{\circ} 57^{\prime} \mathrm{N}, 128^{\circ} 19^{\prime} \mathrm{W}$ & 4800 & 16 & 130 & N/A & $65(16.8)$ & 100 \\
\hline ECHO 1 & $14^{\circ} 40^{\prime} \mathrm{N}, 126^{\circ} 25^{\prime} \mathrm{W}$ & 4500 & 15 & 135 & N/A & $42(5.5)$ & 113 \\
\hline
\end{tabular}


checked with the CCFZ specimens, and remain as a separate dataset in this analysis. Unique species code numbers were assigned to distinguish species unknown to science.

Analysis of species diversity. We investigated 2 types of species diversity differentiated by the spatial scale considered: (a) local or within-site, diversity, sometimes referred to as alpha diversity, and (b) species turnover between sites, which some authors have termed beta diversity (Whittaker 1972, Gray 2000). We measured local diversity as the diversity of a single site (e.g. EqPac $0^{\circ} \mathrm{N}$ ), encompassing the total diversity of sampling units (box cores) at that site. We evaluated species turnover by analyzing the similarity of sites in terms of species composition based on species lists, and the distribution of individuals among species, using multivariate and parsimony methods. The spatial scale at which turnover was analyzed was determined by the distance between sites, in this case ranging from 200 to $3000 \mathrm{~km}$.

Species diversity analysis was undertaken using Biodiversity Pro (McAleece et al. 1996). Shannon $H^{\prime}$ and rarefaction analysis were used as measures that are sensitive to both equitability and richness while being relatively sample size independent (Sanders 1968, Hurlbert 1971, Fager 1972, Gage \& May 1993). The term 'species diversity' is used throughout this paper to indicate measures of diversity that incorporate both equitability and richness. Regression analysis was carried out using Statview 5.0. PAUP v.3.0 (Swofford 1993) was used to classify sites based on species pres-

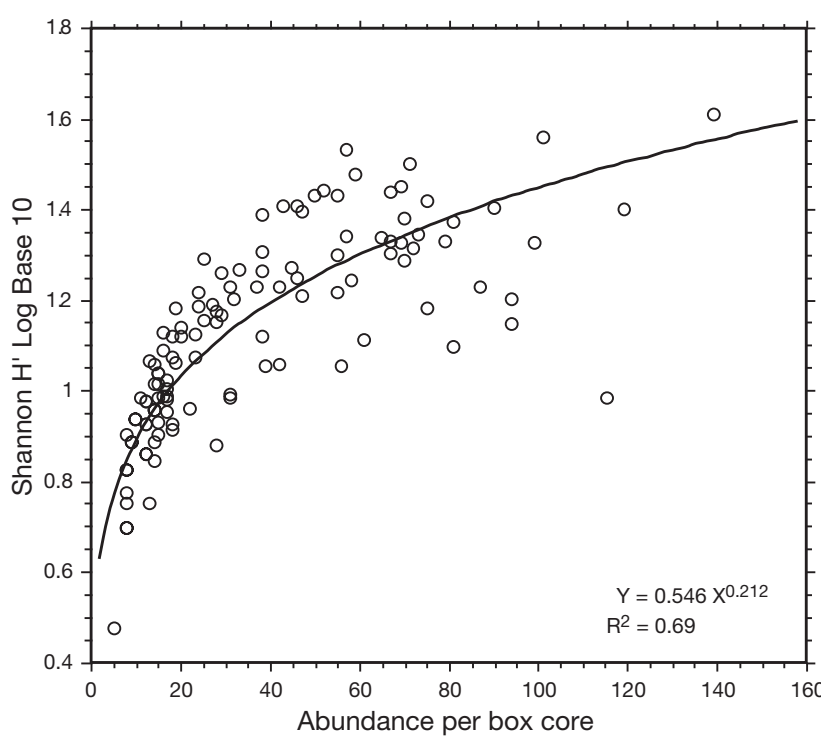

Fig. 2. Density-dependence of the Shannon diversity index $\left(H^{\prime}\right)$, for abyssal polychaete species in the central Equatorial Pacific. Data from 94 USNEL spade box cores. Non-linear regression with power transformation ence and to graphically illustrate comparative species richness using the parsimony method (Lambshead \& Paterson 1986, Glover et al. 2001). The Normalized Expected Species Shared (NESS) measure of faunal similarity was calculated using the computer program COMPAH96 (http://www.es.umb.edu/edgwebp.htm). This computer program uses a modified version of the original NESS calculation (NNESS) (Grassle \& Smith 1976).

\section{RESULTS}

\section{Local diversity}

From the EqPac and HOT sites, a total of 177 polychaete species were recorded from $2.94 \mathrm{~m}^{2}$ of seabed; from the DOMES A, ECHO 1 and PRA sites in the CCFZ region, the total was 183 species from $21 \mathrm{~m}^{2}$ of seabed (Table 1). $70 \%$ of identifiable specimens could be assigned to known genera, but only about 5 to $10 \%$ could be identified as a previously named species; thus, the vast bulk (>90\%) of the collected polychaete species are undescribed taxonomically (i.e. they are new to science). The polychaete assemblage was highly dominated by the families Cirratulidae ( 17\%), Spionidae $(\sim 17 \%)$, Paraonidae ( 17\%), Sabellidae ( 10\%) and Syllidae $(\sim 10 \%)$ at all stations. These were also the most speciose families. The highest polychaete abundance occurred at the EqPac $0^{\circ} \mathrm{N}, 2^{\circ} \mathrm{N}$ and $5^{\circ} \mathrm{N}$ sites, and the lowest at the $9^{\circ} \mathrm{N}$ site, the HOT site and the DOMES A site. Polychaete abundance at the PRA site was similar to that at the EqPac $2^{\circ} \mathrm{N}$, and that at the ECHO 1 site fell midway between the high-POC flux EqPac sites $\left(0^{\circ}\right.$ to $\left.5^{\circ} \mathrm{N}\right)$ and the oligotrophic DOMES A site. The greatest number of species was found at the most intensively sampled site, DOMES A, while the lowest number of species were found at the HOT station, where both abundance and sampling intensity were low (Table 1).

To account for variability in both species abundance and sampling intensity, the Shannon diversity index $\left(H^{\prime}\right)$ and rarefaction methods were used. $H^{\prime}$ may be sensitive to sample size, i.e. to the number of individuals in a sample (Lambshead et al. 1983, Soetaert \& Heip 1990). The relationship between $H^{\prime}$ and the abundance of polychaetes per box core in our data (Fig. 2) indicates that, below a level of approximately 35 individuals per box core, $H^{\prime}$ is strongly density-dependent. Above this level, $H^{\prime}$ ranges from 0.96 to 1.6 , but little variability is explained by abundance, indicating that $H^{\prime}$ has become relatively density-independent.

Given the apparent density-independence of $H^{\prime}$ in the higher-abundance samples, the diversity statistic was calculated for only those samples containing 


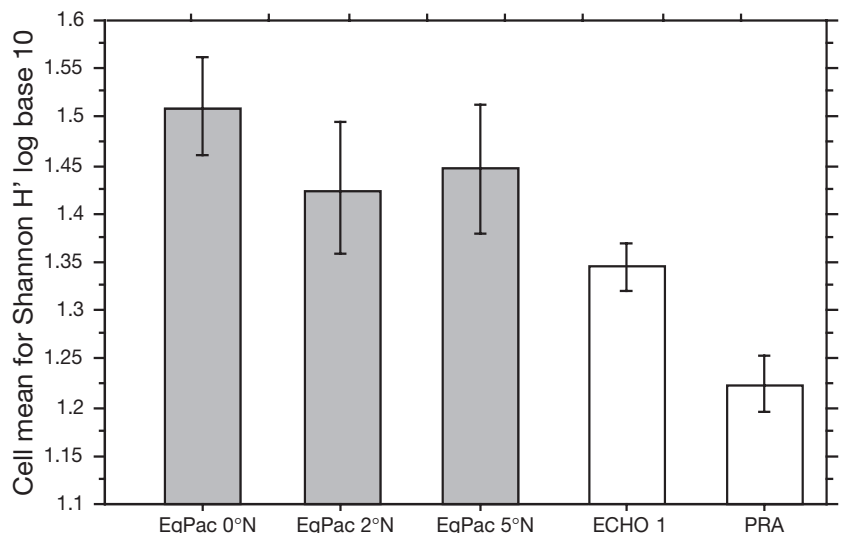

Fig. 3. Shannon diversity index $\left(H^{\prime}\right)$ for abyssal polychaete species in the central equatorial Pacific. All samples with less than 35 individuals were excluded from this analysis. Grey bars indicate those sites lying under the productive zone. EqPac $0^{\circ} \mathrm{N}, 2^{\circ} \mathrm{N}$ and $5^{\circ} \mathrm{N}$ show no significant differences in diversity (ANOVA $\mathrm{p}>0.05$ ). ECHO 1 site has significantly lower diversity than the EqPac sites (ANOVA $p<0.05$ ), PRA site has significantly lower diversity than ECHO 1 site $($ ANOVA $p<0.05)$. Error bars are \pm SE

greater than 35 individuals (Fig. 3). This excluded samples from very oligotrophic regions at $9^{\circ} \mathrm{N}, \mathrm{HOT}$ and DOMES A. The EqPac $0^{\circ} \mathrm{N}, 2^{\circ} \mathrm{N}$ and $5^{\circ} \mathrm{N}$ sites showed the highest diversity when measured in this way; species diversity at the CCFZ sites ECHO 1 and PRA was significantly lower, and it was significantly lower at PRA than at ECHO 1 (Fig. 3).

In a similar analysis using rarefaction at a sample size of 30 individuals $\left[\mathrm{E}\left(\mathrm{S}_{30}\right)\right]$ on replicate box cores, the EqPac $0^{\circ} \mathrm{N}, 2^{\circ} \mathrm{N}$ and $5^{\circ} \mathrm{N}$ sites again show higher diversity than the CCFZ sites (Fig. 4).

The rarefaction analysis was also conducted on pooled samples (Fig. 5). EqPac $2^{\circ} \mathrm{N}$ shows the highest diversity (82 species for 163 individuals) followed by $5^{\circ} \mathrm{N}$ (75 species for 163 individuals), $0^{\circ} \mathrm{N}$ (71 species for 163 individuals), ECHO 1 (60 species for 163 individuals), DOMES A (56 species for 163 individuals) and PRA (47 species for 163 individuals).

In order to evaluate directly the relationship between POC flux, or appropriate proxies, and polychaete species diversity, a relatively low $\mathrm{E}(\mathrm{S})$ value was selected so that the $9^{\circ} \mathrm{N}$ and HOT $23^{\circ} \mathrm{N}$ sites could be included. No deep POC flux data are available for the CCFZ sites so we used macrofaunal abundance (no. $\mathrm{m}^{-2}$ ) as a proxy for POC flux. A number of studies have documented a strong positive correlation between POC flux and macrofaunal abundance in the deep sea (Sibuet et al. 1989, Cosson et al. 1997, Smith et al. 1997, Etter \& Mullineaux 2001, Glover et al. 2001, Smith \& Demopoulos in press); polychaetes typically make up 60 to $70 \%$ of deep-sea macrofaunal abun-

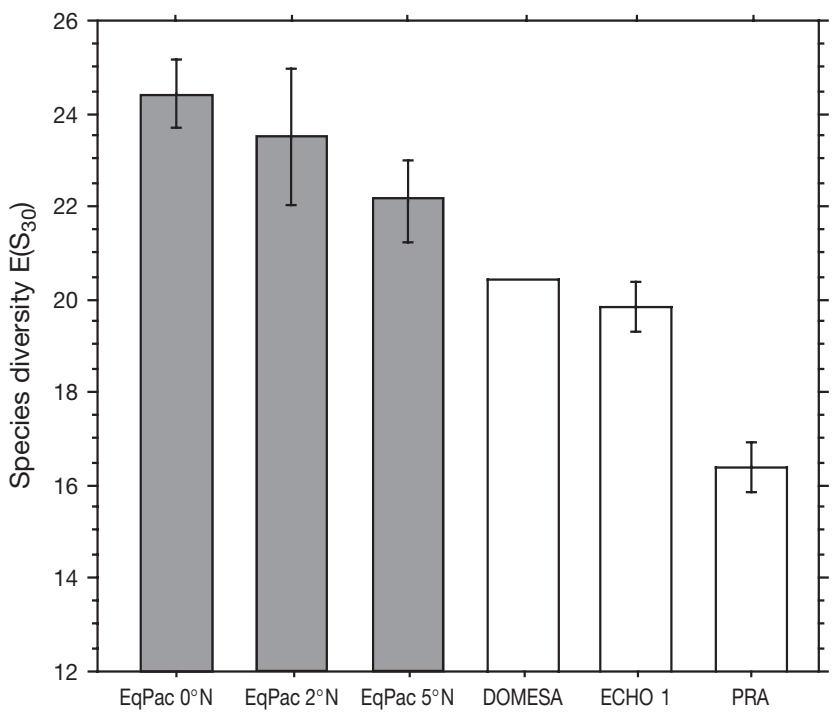

Fig. 4. Local species diversity of abyssal benthic polychaetes in the central equatorial Pacific. Mean $\mathrm{E}\left(\mathrm{S}_{30}\right)$ from a rarefaction analysis. The EqPac sites showed no significant differences in diversity (ANOVA $\mathrm{p}>0.05$ ). The ECHO 1 site is significantly lower in diversity than EqPac $0^{\circ} \mathrm{N}$ and $2^{\circ} \mathrm{N}$ sites (ANOVA $\mathrm{p}<0.05$ ), but not the $5^{\circ} \mathrm{N}$ site. PRA is significantly lower in diversity than all the remaining sites. DOMES A did not have enough box cores with more than 30 individuals for a statistical analysis to be undertaken. Error bars are \pm SE

dance (e.g. Smith \& Demopoulos in press), justifying their use a flux proxy. At $\mathrm{E}\left(\mathrm{S}_{20}\right)$, there was no obvious relationship between either POC flux or polychaete abundance and polychaete species diversity across our sites (Fig. 6).

\section{Species turnover}

Using the principle of maximum parsimony (Lambshead \& Paterson 1986, Bellansantini et al. 1994, Glover et al. 2001), the abyssal sites were classified according to species presence (Fig. 7). In the EqPac region, the 3 sites lying under the influence of equatorial upwelling (also the spatially closest sites) form a unique group, strongly supported by 21 species which occur at all 3 sites. In the CCFZ region, the 2 spatially closest sites, ECHO 1 and PRA, formed a unique cluster, supported by 25 species. All sites exhibit a long tail of rare species that were collected at only a single site. These species are hereafter termed 'unique' species.

Multivariate analysis using NNESS (which takes into account the relative abundance of both rare and abundant species) further supports this geographic grouping (Fig. 8). For the EqPac sites, percentage similarity varies from 30 to $70 \%$ at $m=5$ (where $m$ is the subsample size used to calculate NNESS) and from 25 to $65 \%$ at $m=15$. Higher values of $m$ are more sensitive 

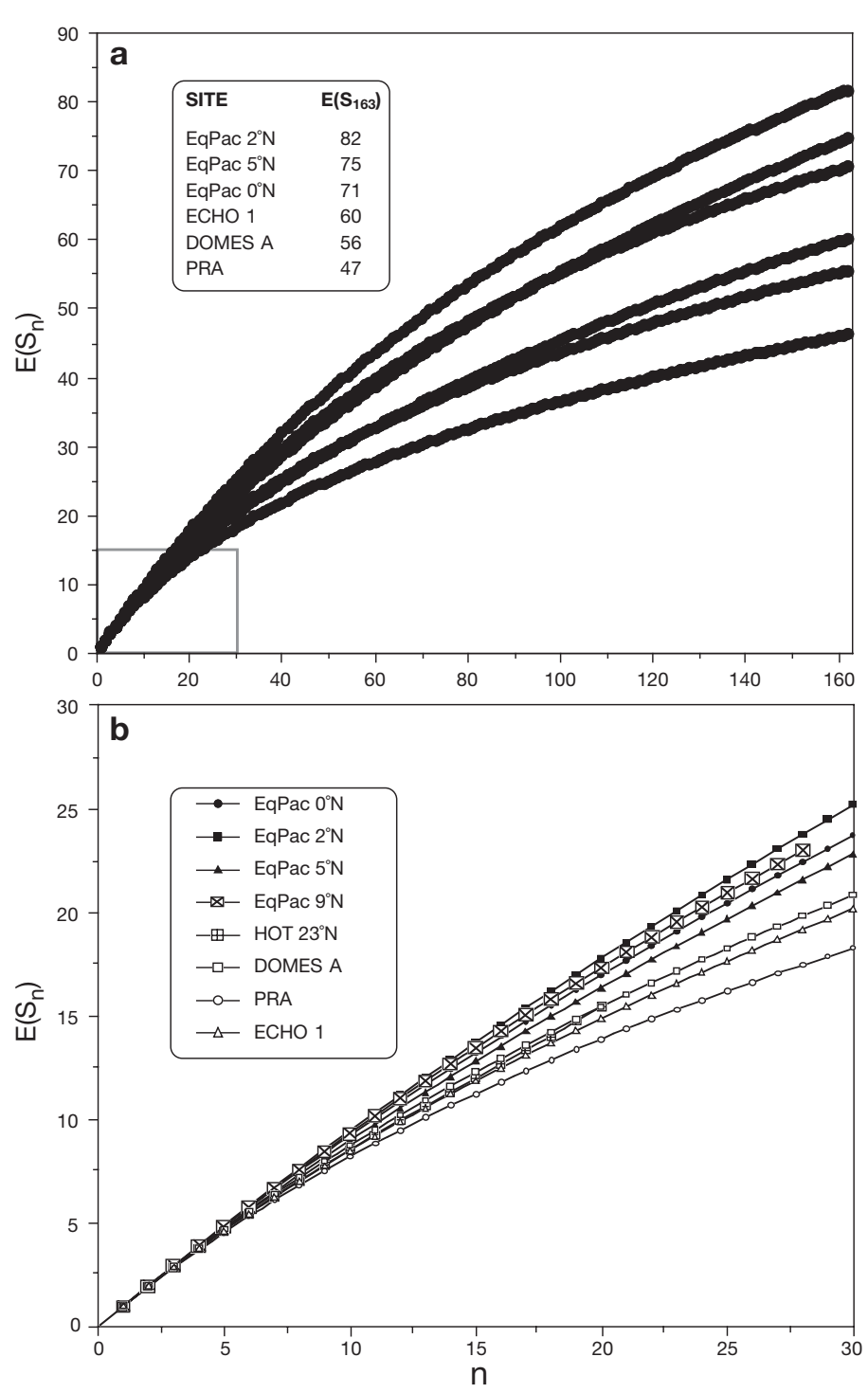

Fig. 5. Local species diversity of abyssal benthic polychaetes in the central equatorial Pacific. Rarefaction curves (a) calculated from pooled box-core samples. Inset (b) shows the same data but with the axes enlarged from 0 to 30 individuals, to allow comparisons at small sample sizes

to the contribution of rare species; as $m$ approaches 1 , the analysis converges to the Morista-Horn presence/absence index (Gallagher 1996). As would be expected, increasing the sensitivity to rare species reduces the overall similarity; at $m=15$, EqPac $9^{\circ} \mathrm{N}$ and HOT $23^{\circ} \mathrm{N}$ sites no longer form a supported group, probably because the total species pool is poorly sampled at these sites due to small sample sizes and faunal densities.

In the CCFZ region, the 2 physically closest sites, ECHO 1 and PRA, form a consistent cluster, at both high and low values of $m$. When only dominant species are taken into account $(m=10)$, all sites show similarity
EqPac $2^{\circ} \mathrm{N}$

EqPac $5^{\circ} \mathrm{N}$ EqPac $0^{\circ} \mathrm{N}$ ECHO 1 DOMES A PRA levels of 73 to $74 \%$, including DOMES A and PRA, which are separated by $2700 \mathrm{~km}$. When the influence of rare species is included at $m=200$, the similarity level of DOMES A and PRA drops to $56 \%$.

At each site, a certain proportion of individuals fall into species that may be termed 'unique', 'widespread' or 'ubiquitous'. Unique species are those that were collected at 1 site only, widespread species are defined as occurring in at least 2 sites, and ubiquitous species were recorded at all sites within a data set (i.e. EqPac or CCFZ stations). In terms of species composition (Fig. 9a), each site contained a substantial proportion of unique species, varying from $20 \%$ at PRA to over $50 \%$ at $2^{\circ} \mathrm{N}$. However, in general, the majority of species found at any single site were widespread or ubiquitous across sites separated by 200 to $3000 \mathrm{~km}$. When abundance is taken into account (Fig. 9b), this pattern is reinforced, with 70 to $90 \%$ of individuals belonging to widespread or ubiquitous species. In other words, at all sites within each data set, the fauna is dominated by a core group of the same, abundant species. The many rare species make only a small contribution ( $\sim 10$ to $30 \%$ ) to the overall abundance of polychaetes at any site.

\section{DISCUSSION}

\section{Relationship between productivity and diversity at local scales}

The highest local diversity was recorded at EqPac sites $0^{\circ} \mathrm{N}, 2^{\circ} \mathrm{N}$ and $5^{\circ} \mathrm{N}$ (Figs. 3, $4 \& 5$ ). These sites showed significantly higher diversity than the sites in the CCFZ region. However, when POC flux is plotted against local diversity at $\mathrm{E}\left(\mathrm{S}_{20}\right)$, no clear relationship between diversity and productivity is evident (Fig. 6a). Furthermore, including the data from the CCFZ, and plotting polychaete abundance (a proxy for deep POC flux) against local diversity also shows no obvious pattern.

Small sample sizes at $9^{\circ} \mathrm{N}$ and $\mathrm{HOT} 23^{\circ} \mathrm{N}$ may be obscuring a productivity-diversity relationship. At low $\mathrm{E}\left(\mathrm{S}_{\mathrm{x}}\right)$ levels, rarefaction is more sensitive to evenness than to species richness. Sites can show similar levels of evenness, but in fact display differing overall species richness (Gage \& May 1993). When higher levels of $\mathrm{E}\left(\mathrm{S}_{\mathrm{x}}\right)$ are used (Fig. 5a), and the $9^{\circ} \mathrm{N}$ and HOT sites excluded, diversity is significantly higher at the more productive sites.

Slightly higher species diversity at the 0 to $5^{\circ} \mathrm{N}$ sites compared to those in the CCFZ region, does not however, imply a strong 'relationship' between productiv- 
Fig. 6. Local species diversity of abyssal benthic polychaetes in the central equatorial Pacific as a function of (a) annual particulate organic carbon flux and (b) benthic polychaete abundance. POC flux data are from Honjo et al. (1995) as recalculated in Smith et al. (1997)

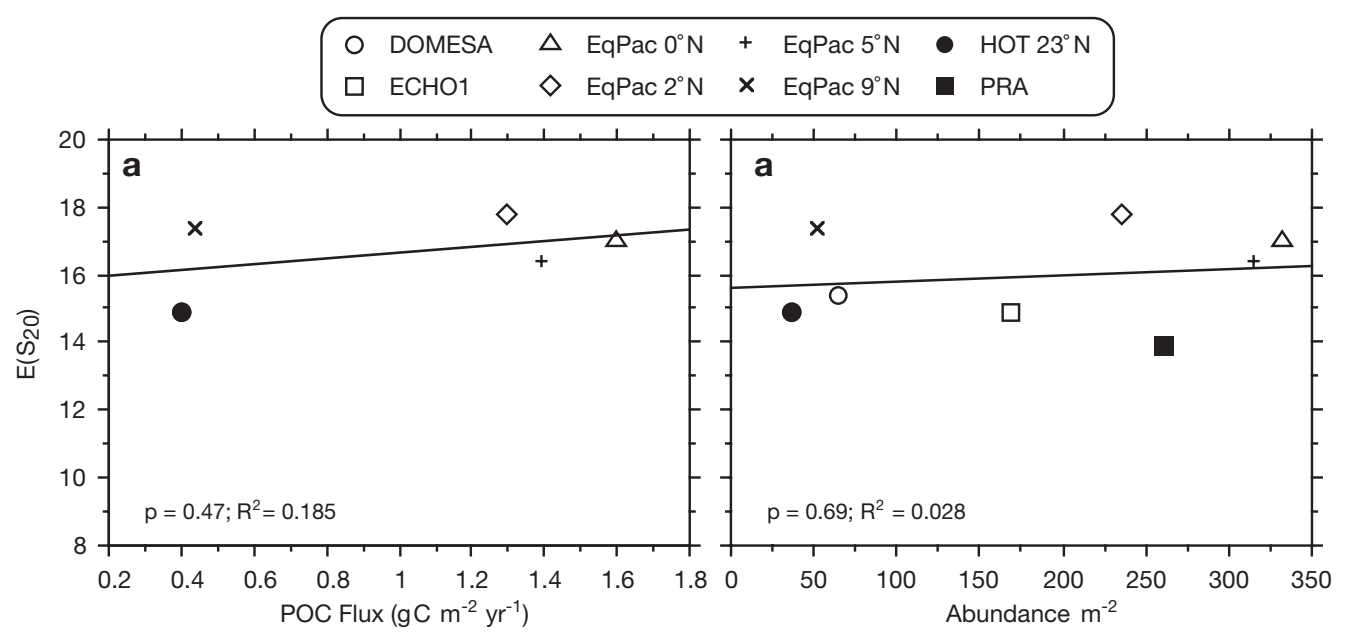

ity and diversity, as has been reported in other ecosystems. For terrestrial plants, monotonic decreases in diversity with increasing productivity have been reported in small-scale plots (Huston 1979, Tilman 1982). At larger scales, a unimodal pattern has been reported for small mammals (Rosenzweig \& Abramsky 1993) and freshwater zooplankton (Rosenzweig 1992).

Ocean depth has traditionally been viewed as a useful inverse proxy of benthic productivity. For this reason, studies of depth-related diversity patterns have been used to explore relationships between productivity and diversity (Rex 1973, 1977, 1981, Huston 1979, Lambshead 1993, Rosenzweig 1995, Cosson-Sarradin et al. 1998). In the cited studies, diversity appears to peak at depths between 2000 and $3000 \mathrm{~m}$. While this pattern is consistent with a unimodal productivity versus diversity relationship, many other depth-varying factors could lead to a bathyal peak in diversity. These include bathymetric boundary constraints (Pineda \& Caswell 1998), variations in sediment grain-size diver- sity (Etter \& Grassle 1992), large-scale habitat mosaics resulting from submarine canyons and turbidity flows (Levin et al. 2001), variable current regimes, historical contingencies (Etter et al. 1999, Rogers 2000) and latitudinal effects (Rex et al. 1993, 1997, 2000). It is far from obvious that productivity plays an important role in this process.

The central equatorial Pacific abyssal plain is a much simpler system in which to test productivity-diversity relationships in the deep sea, because many variables (e.g. depth, terrigenous input, hydrodynamic regime) appear to be relatively constant. We find weak support for a monotonic increase in diversity with productivity, and no evidence of a unimodal relationship, as predicted from a number of ecological studies (Fig. 6) (Huston 1979, Rosenzweig 1995). We can extend the deep-sea productivity versus diversity analysis across basins by including data from the North Atlantic abyss, and using a rarefaction sample size more sensitive to species richness $\left(\mathrm{E}\left(\mathrm{S}_{80}\right)\right)$ (Fig. 10). We still find that only
Fig. 7. Maximum parsimony classification of sites from the central equatorial Pacific abyss based on polychaete species presence. Branch lengths are scaled to the number of species defining each geographic clade, numbers next to branches indicate the number of species that define that particular clade. (a) Shortest tree of 105 potential arrangements for EqPac sites, (b) shortest tree of 3 potential arrangements for CCFZ sites

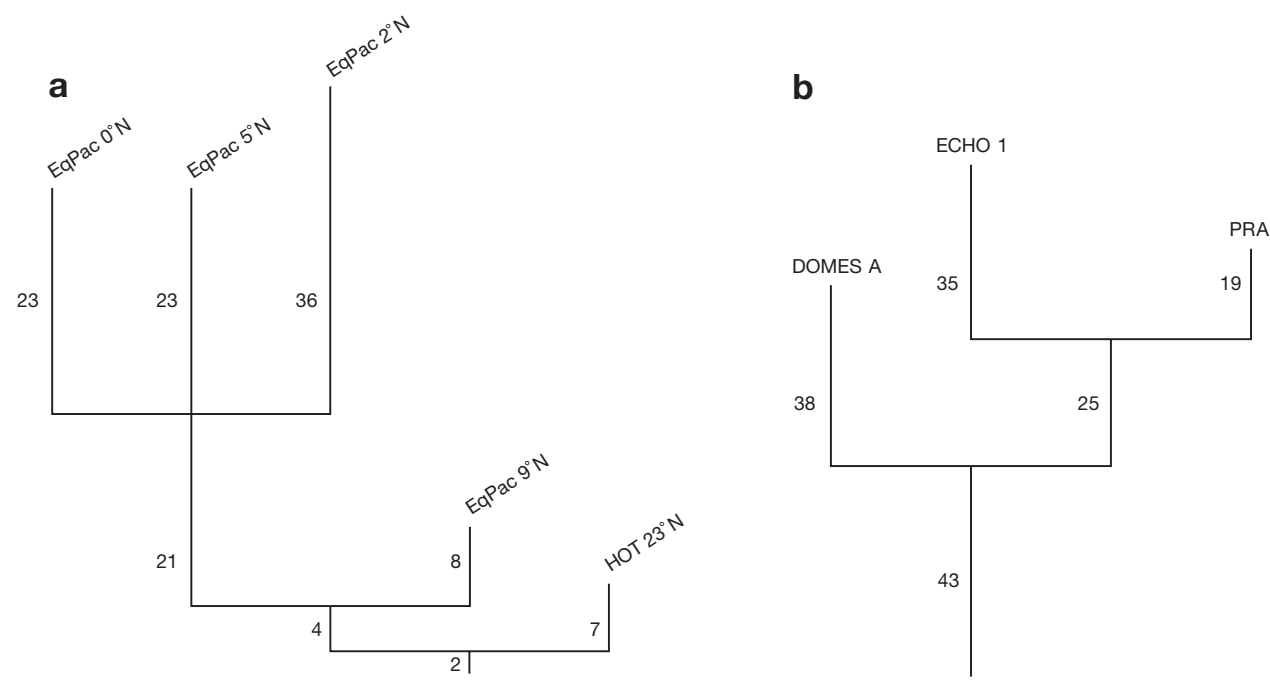


a
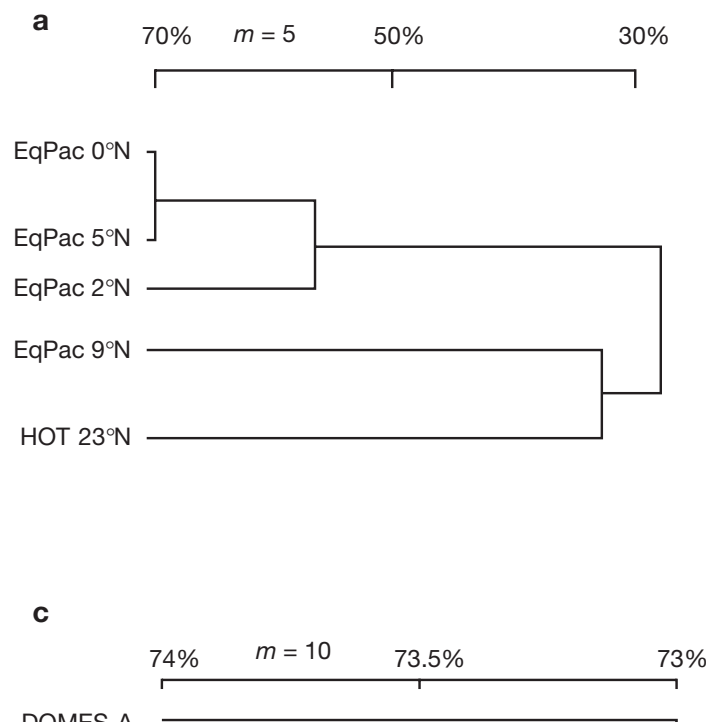

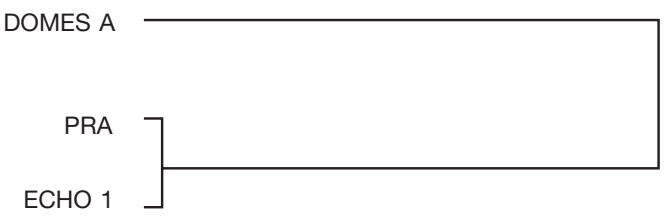

\begin{tabular}{rr|r|} 
DOMES A \\
PRA \\
ECHO 1$]$
\end{tabular}

\begin{tabular}{rr|r|} 
DOMES A \\
PRA \\
ECHO 1$]$
\end{tabular} b
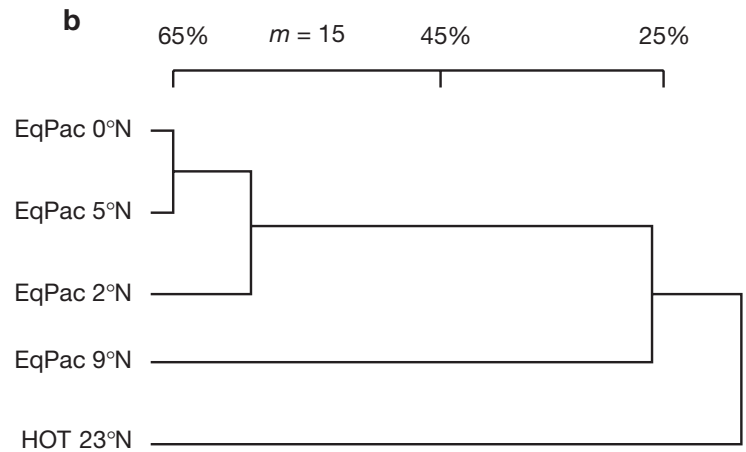

d

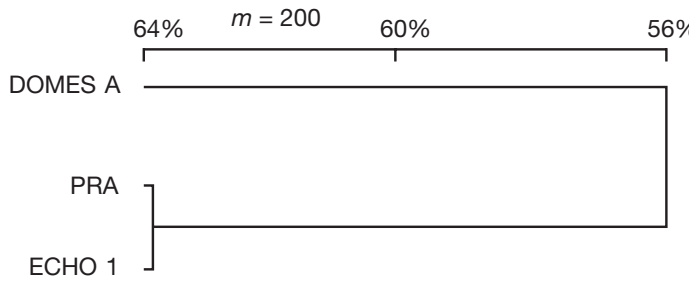

Fig. 8. NNESS analysis of polychaete assemblages from the central equatorial Pacific. (a,b) EqPac and HOT sites at $m=5$ and $m=15$, clustered using flexible sorting $(\beta=-0.25)$. (c,d) CCFZ sites at $m=10$ and $m=200$ clustered using flexible sorting $(\beta=-0.25)$. At higher values of $m$, the influence of rare species is more pronounced, at lower values, the influence of dominant species more pronounced

about $20 \%$ of the variance in diversity may be explained by productivity, when using polychaete abundance as a proxy for POC flux. It should be noted that our abyssal Pacific stations span a 4 -fold dynamic range in productivity; this is comparable to the productivity range over which unimodal diversity patterns have been documented for terrestrial systems (Rosenzweig \& Abramsky 1993, Rosenzweig 1995). In addition, the lower end of our productivity range falls in the oligotrophic abyss, one of the least productive habitats on the Earth's surface (Hessler \& Jumars 1974, Smith \& Demopoulos in press). If very low productivity universally depresses local species diversity, the effect is modest in the oligotrophic abyssal Pacific.

We suspect that variations in diversity in the abyssal Pacific, and the abyss worldwide, are created by a suite of local and regional factors. For example, on the EqPac JGOFS benthic leg in 1992, the 0 to $5^{\circ} \mathrm{N}$ sites were characterized by the presence of recently-accumulated phytodetritus deposits (Smith et al. 1996), increased bioturbation activity (Smith et al. 1997), increased microbial biomass (Smith et al. 1997) and altered sedimentary characteristics in the form of larger grain size and a higher proportion of foraminiferal tests relative to $9^{\circ} \mathrm{N}$ (Berelson et al. 1994, Stephens et al. 1997). Measurable quantities of chlorophyll $a$, excess ${ }^{234}$ Thorium, phytoplankton with intact chloroplasts and high respiration rates at $\mathrm{EqPac} 0^{\circ} \mathrm{N}, 2^{\circ} \mathrm{N}$ and $5^{\circ} \mathrm{N}$ (Smith et al. 1997) contrast sharply with the relatively refractory nature of sediments at $9^{\circ} \mathrm{N}$, and our sites in the CCFZ region.

Other studies document a small but apparently significant decrease in nematode diversity from the highflux $0^{\circ} \mathrm{N}$ to $5^{\circ} \mathrm{N}$ region to the low flux $9^{\circ} \mathrm{N}$ region (Brown et al. 2001, Lambshead et al. 2002). They attributed higher diversity at 0 to $5^{\circ} \mathrm{N}$ to the presence of phytodetritus.

Patchy deposition of ephemeral resources (e.g. phytodetritus), has been postulated to promote local species diversity in the deep sea (e.g. Grassle \& MorsePorteous 1987, Grassle 1989, Grassle \& Maciolek 1992, Snelgrove \& Smith in press). In particular, phytodetrital collection in seafloor depressions and burrows could yield a spatial mosaic that increases diversity on local scales (Grassle \& Maciolek 1992). Thus, the occurrence of phytodetritus at the EqPac stations from 0 to $5^{\circ} \mathrm{N}$ (Smith et al. 1996) might explain the higher local diversity at these stations.

The potential influence of phytodetritus at 0 to $5^{\circ} \mathrm{N}$ must be treated with caution, however. Phytodetritus has only been recorded at these locations during a single cruise (Smith et al. 1996). The wide distribution of the phytodetritus (across 10 degrees of latitude) indicates that it was created by a large-scale bloom; the frequency of occurrence of phytodetritus in the equa- 

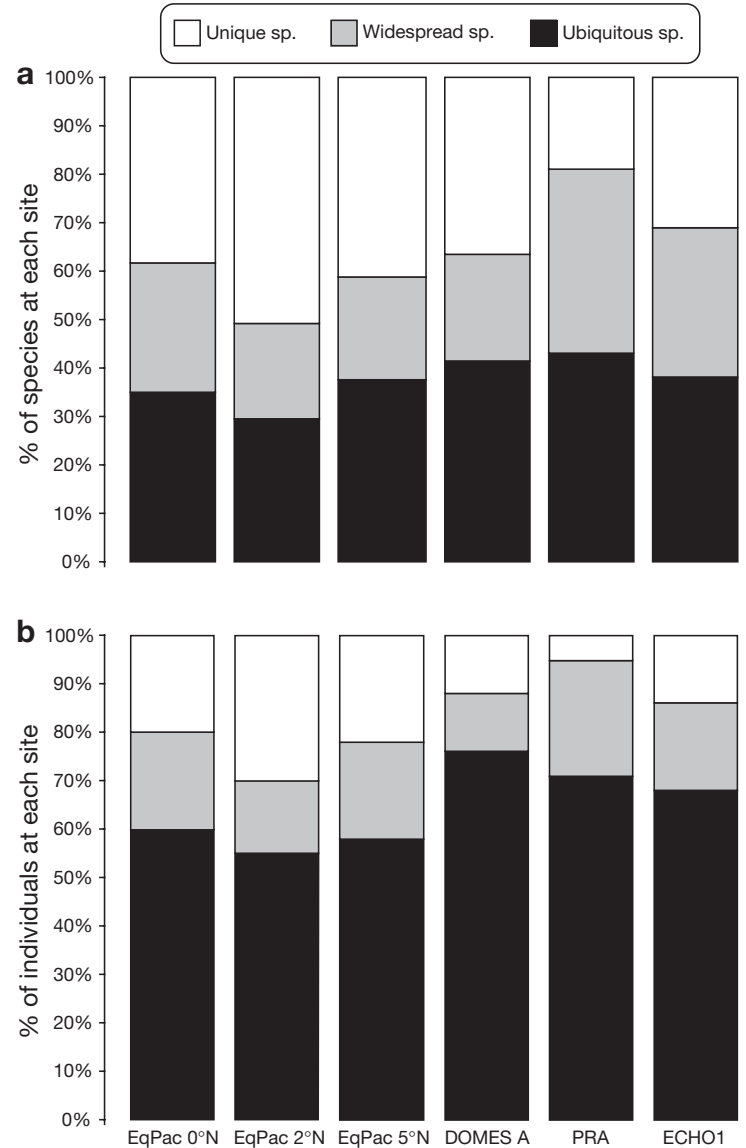

Fig. 9. Distribution patterns of polychaetes from central equatorial Pacific abyssal plains: (a) relative proportion of polychaete species that are unique to a site, present in at least 2 sites, or ubiquitous across all sites, (b) proportion of individuals that belong to species that are unique to a site, present in at least 2 sites, or ubiquitous across all sites

torial Pacific, however, remains to be evaluated. Ascribing regional differences in diversity in the abyssal Pacific to the presence or absence of phytodetritus is premature.

Associated with enhanced productivity at 0 to $5^{\circ} \mathrm{N}$ was the increased abundance of echinoderms, in particular large urchins, which were visible in seabed photographs (Smith et al. 1997). The bioturbation generated by these organisms was 10 -fold greater at 0 to $5^{\circ} \mathrm{N}$ compared to $9^{\circ} \mathrm{N}$ (Smith et al. 1997). Megafaunal abundances, and very likely bioturbation rates, are also much lower at the CCFZ sites than at the 0 to $5^{\circ} \mathrm{N}$ stations (Tilot 1991, Smith \& Demopoulos in press, C. Smith pers. obs.). Evidence from studies in both deep and shallow-water have shown that localized smallscale disturbance may increase diversity (Connell 1978, Sousa 1979, Smith 1986, Kukert \& Smith 1992, Widdicombe \& Austen 1999, Snelgrove \& Smith in press). In the abyssal Pacific, where rates of distur- bance are likely to be very low, enhanced megafaunal activities and bioturbation, such as observed at 0 to $5^{\circ} \mathrm{N}$, seem particularly likely to shift communities towards intermediate levels of disturbance and enhanced diversity (Huston 1979). In situ studies are required, however, to determine whether urchin burrowing disturbance enhances local species diversity at the 0 to $5^{\circ} \mathrm{N}$ stations.

It has been suggested that deep-sea datasets may provide some of the best evidence for productivitydiversity relationships (Rosenzweig 1995). In the abyss, isolated from the influences of depth and terrigenous inputs, we find no evidence for a unimodal relationship between productivity and diversity, and only weak evidence that extremely low productivity may reduce diversity (Fig. 10). While variability in abyssal diversity exists, it cannot be explained exclusively by a single environmental factor such as productivity. As for terrestrial habitats (Rohde 1992), we expect that deep-sea diversity is ultimately controlled by a suite of local and regional factors.

\section{Species turnover in the central Pacific abyss}

Evaluating species turnover in deep-sea samples requires teasing out the effects of under-sampling. We have used 3 approaches: (1) examining the species composition in terms of presence/absence using the principle of maximum parsimony (Fig. 7), (2) investigating the influence of common and rare species on

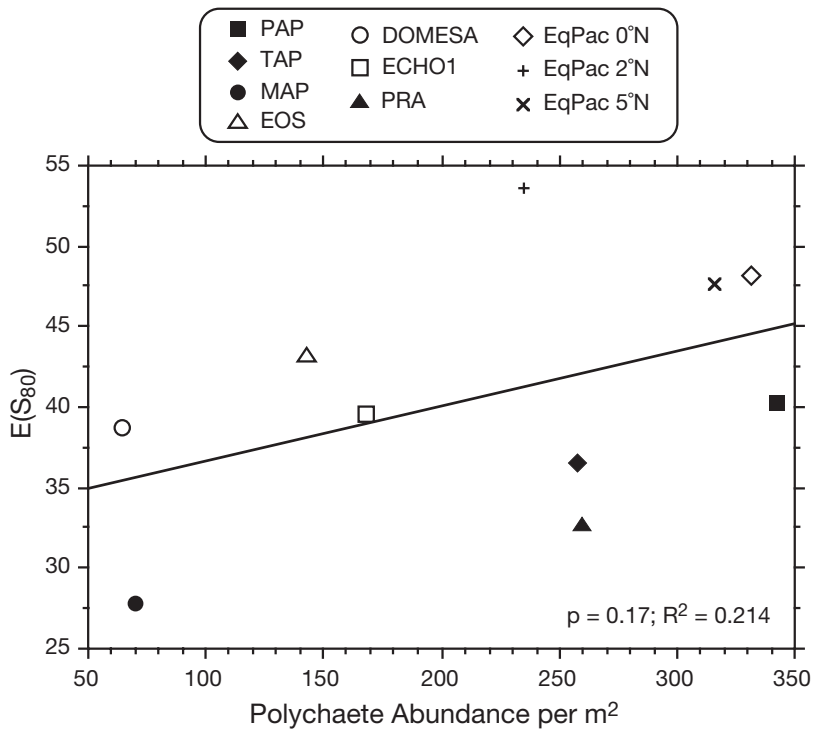

Fig. 10. Relationship between productivity and diversity for polychaetes from central Pacific and north Atlantic abyssal plains. Polychaete abundance is used as a proxy for deep POC flux. Data from PAP, MAP, TAP and EOS sites are from Paterson et al. (1998) and Glover et al. (2001) 
faunal similarity (Fig. 8), and (3) evaluating the percentage contribution of 'unique', 'widespread' and 'ubiquitous' species to the community at each site (Fig. 9).

In the EqPac region, those sites lying under the influence of the upwelling zone form a strongly supported group (Fig. 7a), while the CCFZ sites form 2 groups, based on geographic proximity (Fig. 7b). At all sites, a long tail of unique species is present. When relative abundance is taken into account (Fig. 8), the pattern is essentially similar. Increasing the contribution of rare species to the analysis reduces the overall percentage similarity but does not change the clustering pattern. Finally, when the distribution of species among stations is examined (Fig. 9), it is clear that although each site is highly speciose, all the sites within each data set (i.e. EqPac or CCFZ) contain the same core group of abundant species.

The evidence in favor of high species turnover for polychaetes in the central Pacific abyss is as follows. At each site, there is a long 'tail' of rare, unique species not found at any of the other sites (Fig. 7). This results in relatively low levels of faunal similarity. Additionally, random sub-sampling of the data by the NNESS analysis (Fig. 8) indicates that as sample size increases (at higher values of $m$ ), more rare species are found and faunal similarity decreases. Finally, sites lying under similar productivity regimes, and sites that are proximal in space, form unique clusters based on species composition and community structure (Figs. $7 \&$ 8); this suggests that geographical distance and environmental change are driving species turnover across our sites. These results agree with earlier studies of polychaete species turnover from the north Atlantic and central Pacific, which suggested that turnover was extremely high, and hence regional species richness would be high (Paterson et al. 1998).

In contrast, the evidence in favor of low species turnover in the central Pacific abyss is as follows. At all of the abyssal sites studied, a core group of ubiquitous species that are widespread at scales of at least $3000 \mathrm{~km}$ are numerically dominant (Fig. 9). The 30 to 40 ubiquitous species may represent as much as $90 \%$ of the number of polychaete individuals at each site. Differences between sites could result from an essentially random sub-sampling of the long tail of rare species. These rare species may have very wide distributions, but their comparative rarity, and the problem of under-sampling, results in them having been collected at only a single site. Further supporting this reasoning is the observation that at the CCFZ sites, where many more box cores were taken, the proportion of ubiquitous to unique species is much higher, indicating that at these more intensively sampled sites, a higher proportion of these 'rare' species are found to occur at all 3 sites.
Few studies of the biogeographic ranges of polychaete species in the deep sea have been made. Based on morphological taxonomy studies, species of the aphroditid polychaete Macellicephala appear to have panoceanic distributions, as do several species of the exclusively deep-sea family Fauveliopsidae (Levenstein 1971). The opheliid polychaetes Kesun abyssorum and Travisia profundi are thought to occur in 3 ocean basins, as well as the Antarctic (Levenstein 1972).

Re-examination of type material of the polychaete Laetmonice benthaliana from the Danish Galathea expedition suggested that the species has a panoceanic, cosmopolitan distribution (Kirkegaard 1994). The sigalionid polychaete Leanira quatrefagesi has also been shown to occur in all oceans. Out of the 6 species investigated, 4 were shown to have worldwide distributions, and 2 were widespread across at least 2 oceans. Kirkegaard concluded that '...there is very little variation in morphology and size over large geographical distances'. None of these species, however, were actually recorded from the abyssal sites in this study. Their extremely low density, and the fact that they were mainly collected using bottom-trawls rather than box cores may explain this observation. More recent data on deep-sea Atlantic asteroids, gastropods and bivalves suggest low levels of species turnover in bathyal to abyssal species compared to shelf species (Clark \& Downey 1992, Etter et al. 1999, Price et al. 1999).

However, molecular studies have highlighted the potential for cryptic species in morphologically similar individuals (Grassle \& Grassle 1977, Etter et al. 1999, Knowlton 2000, Westheide \& Hass-Cordes 2001). Many traditional taxonomic assessments of cosmopolitan species may need re-evaluation using molecular methods, and species distributions may be much narrower than inferred from morphological analyses. Molecular studies of the highly mobile amphipod Eurythenes gryllus have found cryptic and divergent populations, some in close proximity (France \& Kocher 1996). Given that the mobility of the average deep-sea polychaete will be less than that of this abyssopelagic scavenging amphipod, the presence of undetected cryptic species may depress our estimates of diversity.

Along the EqPac transect, nematode species turnover is thought to be high, with a distinct 'phytodetrital' fauna at 0 to $5^{\circ} \mathrm{N}$ (Brown 1998, Lambshead et al. 2002). For nematodes at least, areas such as the central Pacific may be subdivided into distinct biogeographical zones, dependent on the dynamics of the upper ocean ecosystem and the amount and quality of export production (Smith et al. 1997).

Our data are not consistent with the high species turnover inferred for nematodes (Brown 1998, Lambshead et al. 2002). Our EqPac sites, and our CCFZ sites, 
appear to be faunistically very similar, differing primarily in the make up of the rare species pool. However, further sampling efforts are needed, using both morphological and molecular approaches, to determine whether 'rare' species actually have very widespread distributions and are simply undersampled. If further sampling efforts reveal a unique, endemic fauna at each site, closely related to between-site distance, then species turnover for polychaetes may be as high as that for nematodes, and species extinction might be a significant risk from large-scale anthropogenic disturbances, such as manganese-nodule mining (ISA Sanya report 1998).

\section{Comparative species richness of the equatorial Pacific abyss}

Local diversity of polychaetes in the central equatorial Pacific abyss is clearly very high. $\mathrm{E}\left(\mathrm{S}_{30}\right)$ at a single site in the Pacific abyssal Peru Basin was in the range 18 to 22 (Borowski \& Thiel 1998), which is similar to our CCFZ sites, and lower than at the productive EqPac sites (e.g. $\mathrm{E}\left(\mathrm{S}_{30}\right)=24.5$ at $0^{\circ} \mathrm{N}$ (Fig. 4)). Levin \& Gage (1998) report $\mathrm{E}\left(\mathrm{S}_{30}\right)$ values of 3 to 23 for slope depths of 220 to $3400 \mathrm{~m}$ in the Pacific and Indian Oceans; these values fall below those from the EqPac 0 to $5^{\circ} \mathrm{N}$ sites. Hessler \& Jumars (1974) also report lower $\mathrm{E}\left(\mathrm{S}_{30}\right)$ values of 12 to 18 at the 5600 m depth CLIMAX II locality in the central Pacific gyre.

Grassle \& Maciolek (1992) reported a total of 798 species from $21 \mathrm{~m}^{2}$ on the northwest Atlantic slope at depths ranging from $1500 \mathrm{~m}$ to $2500 \mathrm{~m}$. Of those 798 species, 385 species $(45 \%)$ were polychaetes. In the present study, 183 species of polychaetes were recorded from $19.25 \mathrm{~m}^{2}$ at CCFZ and 177 species from $2.94 \mathrm{~m}^{2}$ at EqPac. However, the number of individuals (sample size) is much lower in the abyssal Pacific sites, so these figures are not directly comparable. Grassle \& Maciolek (1992) reported that for 1000 polychaete individuals, there were approximately 90 to 100 species. At the PRA site, where 1043 polychaetes were identified, 100 species were found, a comparable level of diversity. At EqPac $2^{\circ} \mathrm{N}, 83$ species were found from just 163 individuals, suggesting substantially higher diversity. Thus, in the Pacific abyss, diversity is comparable to the highest levels of diversity found on the North Atlantic slope, and beneath equatorial upwelling such as at 0 to $2^{\circ} \mathrm{N}$, diversity appears to be higher. We await further studies of polychaete taxonomy, species ranges and reproductive biology before extrapolating further to estimates of global polychaete diversity. However, even with low levels of species turnover, the vastness of the central Pacific abyss may cause it to be one of the most speciose benthic regions on the planet.

\section{Conclusions}

Our data lead to the following conclusions. (1) The relationship between productivity and diversity in the Pacific abyss is not unimodal, and at most weakly increasing, suggesting that extreme oligotrophy does not limit local diversity in the deep sea. (2) For macrofaunal community dominants, there is very low turnover at scales of up to $3000 \mathrm{~km}$ in the abyssal equatorial Pacific. However, for rare species, turnover could be very high, but our sampling intensity is inadequate to draw firm conclusions. More intensive sampling, as well as improved taxonomic resolution, is required to resolve this issue. (3) Local species richness in the central equatorial Pacific abyss is higher than that recorded at abyssal depths in the north Atlantic, and comparable to levels from north Atlantic slope depths. For sites lying under the productive EqPac 0 to $5^{\circ} \mathrm{N}$ sites, polychaete diversity, measured by rarefaction, is the highest yet recorded for the deep sea, suggesting high species diversity in the Pacific compared to the Atlantic.

Resolution of species ranges in the deep ocean requires a new scientific outlook. A combined molecular and morphological approach to evaluate species ranges would be highly valuable. Important conservation issues, such as predicting the impacts of manganese nodule mining, $\mathrm{CO}_{2}$ disposal, iron fertilization and climate change require a better understanding of the diversity, life-history, species ranges and functional ecology of abyssal benthic fauna.

Acknowledgements. The authors would like to acknowledge the Masters and crew of the RV 'Thompson' (EqPac leg), the RV 'Moana Wave' and the RV 'Oceanographer' (CCFZ studies). We thank the many people who helped with the sorting of samples in the laboratory of C.R.S. The EqPac benthic leg was supported by NSF Grant OCE-90-22116 to C.R.S. Leadership of the sampling programs in the CCFZ region were helped by R. Hessler, P. Jumars and F. Spiess. The polychaete specimens from the CCFZ region were identified by $\mathrm{K}$. Fauchald and K. Fitzhugh. A fees-only PhD studentship from the University of Southampton, a stipend from The Natural History Museum, London, and a postdoctoral stipend form NSF Grant OPP-98-15823 to C.R.S. supported A.G.G. while conducting this work. Much of the species identifications and data analyses were carried out at The Natural History Museum, London, and their facilities are gratefully acknowledged. We also thank P. A. Tyler, J. D. Gage and an anonymous reviewer for helpful comments on the manuscript. This is contribution no. 6018 from the School of Ocean and Earth Sciences and Technology, University of Hawaii at Manoa.

\section{LITERATURE CITED}

Behrenfeld MJ, Falkowski PG (1997) Photosynthetic rates derived from satellite-based chlorophyll concentration. Limnol Oceanogr 42:1-20 
Bellansantini D, Dauvin JC, Bellan G (1994) Data analysis in benthic ecology-use of the parsimonious analysis method. Oceanol Acta 17:331-340

Berelson WM, Hammond DE, McManus J, Kilgore TE (1994) Dissolution kinetics of calcium carbonate in Equatorial Pacific sediments. Global Biogeochem Cycles 8:219-235

Borowski C, Thiel H (1998) Deep-sea macrofaunal impacts of a large-scale physical disturbance experiment in the south-east Pacific. Deep Sea Res II 55:55-81

Brown CJ (1998) Effects of a phytodetrital input on nematode communities of the abyssal, equatorial Pacific. $\mathrm{PhD}$ thesis, University of Southampton

Brown CJ, Lambshead PJD, Smith CR, Hawkins LE, Farley R (2001) Phytodetritus and the abundance and biomass of abyssal nematodes in the central, equatorial Pacific. DeepSea Res I 48:555-565

Carney RS, Haedrich RL, Rowe GT (1983) Zonation of fauna in the deep sea. In: Rowe GT (ed) The sea. Wiley-Interscience, New York, p 371-398

Chavez FP, Barber RT (1987) An estimate of new production in the equatorial Pacific. Deep-Sea Res 34:1229-1243

Clark AM, Downey ME (1992) Starfishes of the Atlantic. The Natural History Museum and Chapman \& Hall, London

Connell JH (1978) Diversity in tropical rain forests and coral reefs. Science 199:1302-1309

Cosson N, Sibuet M, Galeron J (1997) Community structure and spatial heterogeneity of the deep-sea macrofauna at three contrasting stations in the tropical northeast Atlantic. Deep-Sea Res I 44:247-269

Cosson-Sarradin N, Sibuet M, Paterson GLJ, Vangriesheim A (1998) Polychaete diversity at tropical Atlantic deep-sea sites: environmental effects. Mar Ecol Prog Ser 165: 173-185

Etter RJ, Grassle JF (1992) Patterns of species diversity in the deep sea as a function of sediment particle size diversity. Nature 360:576-579

Etter RJ, Mullineaux LS (2001) Deep-sea communities. In: Bertness MD, Gaines SD, Hay ME (eds) Marine community ecology. Sinauer Associates, Boston, MA, p 367-392

Etter RJ, Rex MA, Chase MC, Quattro JM (1999) A genetic dimension to deep-sea biodiversity. Deep-Sea Res I 46: 1095-1099

Fager EW (1972) Diversity: a sampling study. Am Nat 106: 293-310

France SC, Kocher TD (1996) Geographic and bathymetric patterns of mitochondrial 16S rRNA sequence divergence among deep-sea amphipods, Eurythenes gryllus. Mar Biol 126:633-643

Gage JD, May RM (1993) A dip into the deep seas. Nature 365:609-610

Gage JD, Tyler PA (1991) Deep-sea biology: a natural history of organisms at the deep-sea floor. Cambridge University Press, Cambridge

Glover AG, Paterson GLJ, Bett B, Gage J, Sibuet M, Sheader M, Hawkins L (2001) Patterns in polychaete abundance and diversity from the Madeira Abyssal Plain, north-east Atlantic. Deep-Sea Res I 48:217-236

Grassle JF (1989) Species diversity in deep-sea communities. Trends Ecol Evol 4:12-15

Grassle JF, Maciolek NJ (1992) Deep-sea species richness: regional and local diversity estimate from quantitative bottom samples. Am Nat 139:313-341

Grassle JF, Morse-Porteous LS (1987) Macrofaunal colonization of disturbed deep-sea environments and the structure of deep-sea benthic communities. Deep-Sea Res 34: 1911-1950

Grassle JF, Smith W (1976) A similarity measure sensitive to the contribution of rare species and its use in investigation of variation in marine benthic communities. Oecologia 25: $13-22$

Grassle JP, Grassle JF (1977) Sibling species in the marine pollution indicator Capitella (Polychaeta). Science 192: 567-569

Gray JS (2000) The measurement of marine species diversity, with an application to the benthic fauna of the Norwegian continental shelf. J Exp Mar Biol Ecol 250:23-49

Hessler RR, Jumars PA (1974) Abyssal community analysis from replicate box cores in the central North Pacific. Deep-Sea Res 21:185-209

Honjo S, Dymond J, Collier R, Manganini SJ (1995) Export production of particles to the interior of the equatorial Pacific Ocean during the 1992 EqPac experiment. DeepSea Res II 42:831-870

Hurlbert SM (1971) The non-concept of species diversity: a critique and alternative parameters. Ecology 52:577-586

Huston M (1979) A general hypothesis of species diversity. Am Nat 113:81-101

ISA Sanya Report (1998) Deep-seabed polymetallic nodule exploration: Development of environmental guidelines. International Seabed Authority, Jamaica

Karl DM, Lukas R (1996) The Hawaii ocean time-series (HOT) program: background, rationale and field implementation. Deep-Sea Res II 43:129-156

Kirkegaard JB (1994) The biogeography of some abyssal polychaetes. Mém Mus Natl Hist Nat 162:471-477

Knowlton N (2000) Molecular genetic analyses of species boundaries in the sea. Hydrobiologia 420:73-90

Kukert H, Smith CR (1992) Disturbance, colonization and succession in a deep-sea sediment community: artificialmound experiments. Deep-Sea Res I 39:1349-1371

Lambshead PJD (1993) Recent developments in marine benthic biodiversity research. Oceanis 19:5-24

Lambshead PJD, Paterson GLJ (1986) Ecological cladisticsan investigation of numerical cladistics as a method of analyzing ecological data. J Nat Hist 20:895-909

Lambshead PJD, Platt HM, Shaw KM (1983) The detection of differences among assemblages of marine benthic species based on an assessment of dominance and diversity. J Nat Hist 17:859-874

Lambshead PJD, Brown CJ, Ferrero TJ, Smith CR, Hawkins LE, Tietjen J (2002) Latitudinal diversity patterns of deepsea marine nematodes and organic fluxes: a test from the central equatorial Pacific. Mar Ecol Prog Ser 236:129-135

Levenstein RY (1971) Polychaeta of the genera Macellicephala and Macelliphaloides (fam. Aphroditidae) from the Pacific. Trudy Inst Okeanol NM PP Sirsova 92:18-35

Levenstein RY (1972) Ecology and zoogeography of some Polychaeta representatives of the abyssal Pacific. Proc R Soc Edinb 73:171-181

Levin LA, Gage JD (1998) Relationships between oxygen, organic matter and the diversity of bathyal macrofauna. Deep-Sea Res II 45:129-164

Levin LA, Etter RJ, Rex MA, Gooday AJ and 5 others (2001) Environmental influences on regional deep-sea species diversity. Annu Rev Ecol Syst 32:51-93

Martin JH, Knauer GA, Karl DM, Broenkow WW (1987) VERTEX: carbon cycling in the northeast Pacific. Deep-Sea Res 34:267-285

McAleece N, Lambshead PJD, Paterson GLJ, Gage JD (1996) Biodiversity Pro. A program for analyzing ecological data. http://www.sams.ac.uk/dml/projects/benthic/bdpro/index. htm

Murray JW, Leborgne R, Dandonneau Y (1997) JGOFS studies in the equatorial Pacific. Deep-Sea Res II 44:1759-1763 
Paterson GLJ, Wilson GDF, Cosson N, Lamont PA (1998) Hessler and Jumars (1974) revisited: abyssal polychaete assemblages from the Atlantic and Pacific. Deep-Sea Res II 45:225-251

Pineda J, Caswell H (1998) Bathymetric species-diversity patterns and boundary constraints on vertical range distributions. Deep-Sea Res II 45:83-101

Piper DZ, Blueford JR (1982) Distribution, mineralogy, and texture of manganese nodules and their relation to sedimentation at DOMES Site A in the equatorial north Pacific. Deep-Sea Res 29:927-952

Price ARG, Keeling MJ, O'Callaghan CJ (1999) Ocean-scale patterns of 'biodiversity' of Atlantic asteroids determined from taxonomic distinctness and other measures. Biol J Linn Soc 66:187-203

Rex MA (1973) Deep-sea species diversity: decreased gastropod diversity at abyssal depths. Science 181:1051-1053

Rex MA (1977) Zonation in deep-sea gastropods: the importance of biological interactions to rates of zonation. In: Keegan BF, O'Ceidigh P, Boaden PJS (eds) Biology of benthic organisms. Pergamon Press, Oxford, p 521-530

Rex MA (1981) Community structure in the deep-sea benthos. Annu Rev Ecol Syst 12:331-353

Rex MA, Stuart CT, Hessler RR, Allen JA, Sanders HL, Wilson GDF (1993) Global-scale latitudinal patterns of species diversity in the deep-sea benthos. Nature 365:636-639

Rex MA, Etter RJ, Stuart CT (1997) Large-scale patterns of species diversity in the deep-sea benthos. In: Ormond RFG, Gage JD, Angel MV (eds) Marine biodiversity: Patterns and processes. Cambridge University Press, Cambridge, p 94-121

Rex MA, Stuart CT, Coyne G (2000) Latitudinal gradients of species richness in the deep-sea benthos of the North Atlantic. Proc Natl Acad Sci USA 97:4082-4085

Rogers AD (2000) The role of oceanic oxygen minima in generating biodiversity in the deep sea. Deep-Sea Res II 47:119-148

Rohde K (1992) Latitudinal gradients in species diversity: the search for the primary cause. Oikos 65:514-527

Rosenzweig ML (1992) Species diversity gradients: we know more or less than we thought. J Mamm 73:715-730

Rosenzweig ML (1995) Species diversity in space and time. Cambridge University Press, Cambridge

Rosenzweig ML, Abramsky Z (1993) How are diversity and productivity related? In: Ricklefs RE, Schluter D (eds) Species diversity in ecological communities: Historical and geographical perspectives. University of Chicago Press, Chicago, p 52-65

Sanders HL (1968) Marine benthic diversity: a comparative study. Am Nat 102:243-282

Sibuet M, Lambert CE, Chesselet R, Laubier L (1989) Density of the major size groups of benthic fauna and trophic input in deep basins of the Atlantic Ocean. J Mar Res 47:851-867

Smith CR (1986) Nekton falls, low-intensity disturbance and community structure of infaunal benthos in the deep-sea. J Mar Res 44:567-600

Smith CR (1992) Cruise report for the US JGOFS Equatorial Pacific benthic cruise (RV 'Thomas Thompson', 30 Oct-13 Dec 1992, TT013) for the laboratory of Craig R. Smith. University of Hawaii at Manoa, Honolulu

Smith CR, Demopoulos A (in press) Ecology of the deep Pacific Ocean floor. In: Tyler PA (ed) Ecosystems of the world, Vol 28: Ecosystems of the deep ocean. Elsevier, Amsterdam

Editorial responsibility: Otto Kinne (Editor),

Oldendorf/Luhe, Germany
Smith CR, Hoover DJ, Doan SE, Pope RH, DeMaster DJ, Dobbs FC, Altabet MA (1996) Phytodetritus at the abyssal seafloor across $10^{\circ}$ of latitude in the central equatorial Pacific. Deep-Sea Res II 43:1309-1338

Smith CR, Berelson W, DeMaster DJ, Dobbs FC, Hammond D, Hoover DJ, Pope RH, Stephens M (1997) Latitudinal variations in benthic processes in the abyssal equatorial Pacific: control by biogenic particle flux. Deep-Sea Res Part B 44:2295-2317

Snelgrove PVR, Smith CR (in press) A riot of species in an environmental calm: the paradox of the species-rich deep sea. Oceanogr Mar Biol Annu Rev

Soetaert K, Heip C (1990) Sample-size dependence of diversity indices and the determination of sufficient sample size in a high-diversity deep-sea environment. Mar Ecol Prog Ser 59:305-307

Sousa WP (1979) Disturbance in marine intertidal boulder fields: the nonequilibrium maintenance of species diversity. Ecology 60:1225-1239

Spiess FN, Hessler R, Wilson G, Weydert M (1987) Environmental effects of deep-sea dredging. SIO Reference Report 87-5, Scripps Inst Oceanogr, San Diego

Stephens MP, Kadko DC, Smith CR, Latasa M (1997) Chlorophyll-a and pheopigments as tracers of labile organic carbon at the central equatorial Pacific seafloor. Geochim Cosmochim Acta 61:4605-4619

Suess E (1980) Particulate organic carbon flux in the oceanssurface productivity and oxygen utilization. Nature 288: 260-263

Swofford DL (1993) Phylogenetic analysis using parsimony (PAUP). Ver. 3.1.1

Tilman D (1982) Resource competition and community structure. Princeton University Press, Princeton

Tilot V (1991) Preliminary report on the description of megafaunal assemblages and manganese nodule coverage along transects taken during the benthic impact experiment cruise. IFREMER, Brest

Waide RB, Willig MR, Steiner CF, Mittelbach G, Gough L, Dodson SI, Juday GP, Parmenter R (1999) The relationship between productivity and species richness. Annu Rev Ecol Syst 30:257-300

Westheide W, Hass-Cordes E (2001) Molecular taxonomy: description of a cryptic Petitia species (Polychaeta: Syllidae) from the island of Mahe (Seychelles, Indian Ocean) using RAPD markers and ITS2 sequences. J Zool Syst Evol Res 39:103-111

Whittaker RH (1972) Evolution and measurement of species diversity. Taxon 21:213-251

Widdicombe S, Austen MC (1999) Mesocosm investigation into the effects of bioturbation on the diversity and structure of a subtidal macrobenthic community. Mar Ecol Prog Ser 189:181-193

Wilson GDF (1990) Biological evaluation of a preservational reserve area 'BEPRA 1'. Cruise report and interim report on laboratory analysis. Scripps Inst Oceanogr, San Diego

Wilson GDF (1992) Biological evaluation of a preservational area-faunal data and comparative analysis. Australian Museum, Sydney

Wilson GDF, Hessler R (1987) The effects of manganese nodule test mining on the benthic fauna in the north equatorial Pacific. In: Spiess FN, Hessler R, Wilson GDF, Weydert $M$ (eds) Environmental effects of deep sea dredging. Scripps Inst Oceanogr, San Diego, p 24-57 